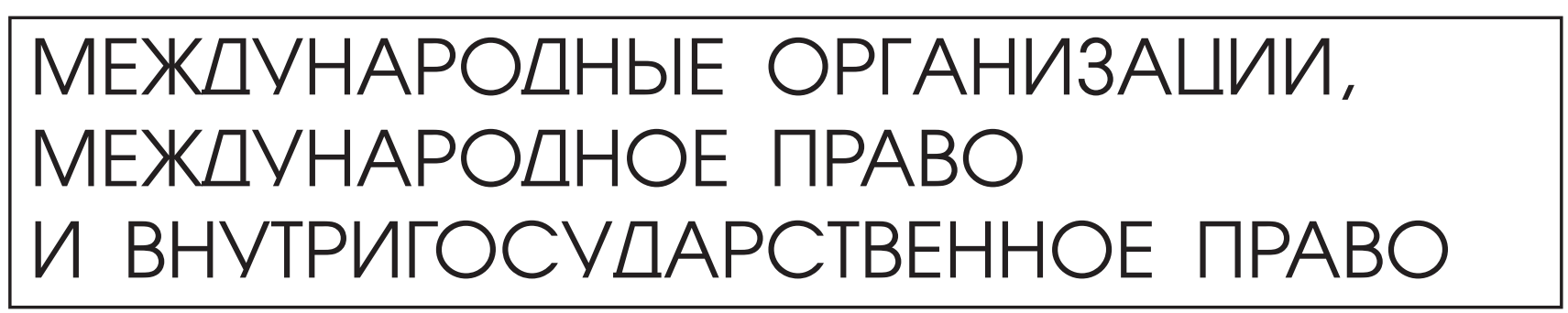

Зацепина Т.Н., Нагорная Э.Н.

\title{
О НЕКОТОРЫХ ПРОБЛЕМНЫХ ВОПРОСАХ ИСПОЛНЕНИЯ ИНОСТРАННЫХ СУДЕБНЫХ АКТОВ В ГОСУДАРСТВАХ - УЧАСТНИКАХ СНГ (НА ПРИМЕРАХ ПРАВОПРИМЕНИТЕЛЬНОЙ ПРАКТИКИ ЭКОНОМИЧЕСКОГО СУДА СНГ)
}

Аннотация. Предметом исследования являются проблемные вопросы применения норм международных договоров, регулирующих исполнение иностранных судебных актов в Содружестве Независимых Государств, выявленные Экономическим Судом СНГ при их толковании. Рассматриваются неоднозначно понимаемые в правоприменительной практике положения о неизвещении о процессе как основании отказа в приведении в исполнение иностранного судебного решения, о возможности исполнения поручений иностранных судов о принятии обеспечительных мер и др. Обращается внимание на прикладное значение проблематики для других интеграционных объединений на пространстве Содружества в силу отсутствия специального международно-правового регулирования вопросов признания и исполнения иностранных судебных решений. Использован сравнительно-правовой анализ международных договоров и законодательства государств - участников СНГ во взаимосвязи с правовыми позициями выстих судебных инстанций Российской Федерации и научными взглядами российских правоведов. Обосновывается вывод о том, что судебные акты Экономического Суда СНГ выявляют проблемные аспекты соотношения международных договоров государств - участников СНГ и норм национального законодательства при исполнении иностранных судебных актов и устанавливают, каким образом эти проблемы могут быть решены. Данные в рамках официального консультативного заключения Суда рекомендаџии о иелесообразности выработки государствами -участниками СНГ на многостороннем (двустороннем) уровне, с учетом международного опыта, единого порядка надлежащего извещчения иностранных лии, а также единого механизма принятия к исполнению (либо отказа в принятии к исполнению) поручений иностранных судов о применении обеспечительных мер, направлены на эффективное трансграничное исполнение судебных и арбитражных решений в рамках Содружества.

Ключевые слова: Содружество Независимых Государств, Экономический Суд, Киевское соглашение, Минская конвенция, Гаагская конвенция, исполнение судебных актов, иностранные судебные решения, надлежащее извещение, обеспечительные меры, исполнительный лист.

Abstract: The subject of this research is the problematic issues of application of norms of international treaties regulating the execution of foreign court orders within the CIS, detected by 
the CIS Economic Court during their interpretation. The authors give attention to the applied significance of the problematics for other integrational unions throughout the Commonwealth due to lack of special international legal regulation of the questions of acknowledgement and execution of foreign court decisions. The authors substantiate the conclusion that the court rulings of the CIS Economic Court reveal the problematic aspects of the correlation between the international treaties of the CIS member-states and the norms of national legislation during execution of foreign court orders, and set the procedure for resolving these issues. Within the framework of official consultative decision of the Court, the recommendations on the reasonableness of development of a unified procedure for due notification of foreign individuals by the CIS member-states on a bilateral level, as well as a unified mechanism of acceptance (or decline) of the foreign court orders, are aimed at the efficient transboundary execution of court and arbitral rulings within the Commonwealth.

Keywords: Commonwealth of Independent States, Economic Court, Kiev Treaty, Minsk Convention, Hague Convention, Execution of court orders, Foreign court rulings, Due notification, Provisional measures, Writ of execution.

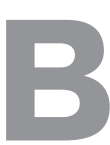
ыбор темы статьи связан с необходимостью выработки в государствах - участниках СНГ, и в том числе в Российской Федерации, общих подходов в сфере исполнения иностранных судебных актов в гражданском и экономическом правосудии. Актуальность проблематики подтверждается тем, что вопрос «Эффективное трансграничное исполнение судебных и арбитражных решений: национальный подход или универсальные критерии?» внесен на обсуждение V Петербургского Международного Юридического Форума 27-30 мая 2015 года.

В ситуации объединения арбитражных судов и судов общей юрисдикции Российской Федерации в единую систему и разработки концепции унифицированного Гражданского процессуального кодекса возникла проблема создания современной и эффективной модели судопроизводства, с сохранением лучших наработок ГПК и АПК. В период формирования концепции нового ГПК значение приобретает, как отмечают ученые-правоведы, максимальное обсуждение проблем законотворчества и правоприменения. Выявление достоинств и недостатков правового регулирования позволит создать обоснованную концепцию развития гражданского процессуального законодательства [1, с. 48, 53].

Достижение этой задачи применительно к судопроизводству, отягощенному иностранным элементом, связано с решением проблемных вопросов соотношения положений международных договоров государств - участников СНГ и норм национального законодательства при исполнении иностранных судебных актов.

Вопросы признания и приведения в исполнение иностранных судебных решений в Содружестве Независимых Государств регулируются Соглашением о порядке разрешения споров, связанных с осуществлением хозяйственной деятельности, подписанным в г. Киеве 20 марта 1992 года (далее-Соглашение от 20 марта 1992 года, Соглашение, Киевское соглашение) [2], Конвенцией о правовой помощи и правовых отношениях по гражданским, семейным и уголовным делам, заключенной в г. Минске 22 января 1993 года (далее Минская конвенция) [3], и Протоколом к ней, подписанным в г. Москве 28 марта 1997 года [4], Конвенцией о правовой помощи и правовых отношениях по гражданским, семейным и уголовным делам, заключенной в г. Кишиневе 
7 октября 2002 года (далее - Кишиневская конвенция) [5].

Российская Федерация является участником Киевского соглашения и Минской конвенции (с Протоколом к ней); кроме того, как и ряд других государств, участвует в двусторонних соглашениях о правовой помощи и правовых отношениях по гражданским, семейным и уголовным делам.

Прикладное значение вышеназванных международных договоров СНГ признается также для других интеграционных объединений, созданных на пространстве Содружества, в силу отсутствия специального международно-правового регулирования вопросов признания и исполнения иностранных судебных решений в рамках этих объединений [6, с.139].

В свете изложенного представляют интерес некоторые проблемные вопросы применения норм указанных договоров, выявленные Экономическим Судом СНГ (далее - Экономический Суд, Суд) при толковании их положений. Осуществление международными региональными судебными органами консультативной юрисдикции, как справедливо подчеркивается авторами, не только оказывает влияние на обеспечение выполнения договорных обязательств по международным договорам, но свидетельствует о готовности судов рассматривать неоднозначные юридические вопросы [7, с.11].

Состоят они в следующем.

Основанием отказа в приведении в исполнение иностранного судебного решения, предусмотренным вышеназванными договорами государств - участников Содружества, в том числе является представление стороной, против которой решение направлено, доказательства того, что другая сторона не была извещена о процессе (пункт г) статьи 9 Соглашения от 20 марта 1992 года), или ответчику не был своевременно и надлежаще вручен вызов в суд (подпункт б) статьи 55 Минской конвенции; подпункт в) статьи 59 Кишиневской конвенции; аналогичная по содержанию норма содержится в двусторонних договорах Российской Федерации.

Норма пункта г) статьи 9 Киевского соглашения, предусматривающего возможность отказа в приведении в исполнение решения, если другая сторона не была извещена о процессе, является, по утверждению C. В. Крохалева, «базовой составляющей процессуального публичного порядка, основанной на принципах состязательности и равенства сторон в процессе» [8]. Закрепленный в процессуальных законах практически всех государств принцип процессуального равенства, одним из элементов которого является в том числе право лица быть выслушанным - право участвовать в судебном заседании, давать суду свои объяснения, делать заявления, заявлять ходатайства, аргументировать свою позицию по делу - является важнейшим процессуальным правилом, обеспечивающим право лица на справедливое судебное разбирательство (права на надлежащий процесс, due process). Суд же обязан создавать условия для осуществления участвующими в деле лицами своих процессуальных прав и контролировать соблюдение соответствующих процессуальных гарантий [9].

Ряд теоретиков (например, Н. Ю. Ерпылева) обосновывают формирование в настоящее время международного гражданско-процессуального права, которое является отраслью международного частного права и состоит из норм национального законодательства и международных договоров, регулирующих процессуальные отношения, осложненные иностранным элементом (международные процессуальные отношения). К числу принципов международного гражданско-процессу- 
ального права Н. Ю.Ерпылева относит в том числе принцип должного извещения и права представить свои объяснения [10].

Проблема правоприменения в данном случае состоит, однако, в том, что порядок извещения сторон о процессе в приведенных нормах Соглашения от 20 марта 1992 года, равно как и Минской и Кишиневской конвенциях, а также двусторонних договорах о взаимной правовой помощи, не конкретизирован. Урегулированный национальными процессуальными законами порядок извещения о судебном процессе является неоднозначным, направленным в основном на обеспечение эффективного и экономичного уведомления, которое позволяет, с одной стороны, обеспечить надлежащую защиту прав участников процесса, в том числе путем сокращения установленного срока рассмотрения спора, а с другой, - минимизировать расходы суда, рассматривающего дело, на такое извещение.

Обобщение Советом председателей высших арбитражных, хозяйственных, экономических и других судов, разрешающих дела по спорам в сфере экономики, материалов практики применения национальными судами положений Соглашения от 20 марта 1992 года показало, что имеют место случаи отказа в приведении в исполнение решений на территории одного государства-участника, которые вынесены по существу спора судом другого государства-участника до получения результатов исполнения собственных поручений об извещении стороны спора. Данные обстоятельства послужили основанием запроса Совета председателей в Экономический Суд о толковании пункта г) статьи 9 Соглашения и разъяснении, что следует понимать под надлежащим извещением стороны о процессе, по результатам рассмотрения которого Судом 26 апреля 2014 года вынесено консультативное заключение № 01-1/4-13 [11].
Изучение международных договоров государств - участников СНГ применительно к запросу, анализ норм национального законодательства и материалов судебной практики по вопросам признания и приведения в исполнение иностранных судебных решений позволили Суду сделать ряд выводов о соотношении норм международных договоров и законодательства государств - участников Содружества, касающихся надлежащего извещения при исполнении иностранных судебных решений.

Согласно правовой доктрине существует три основных способа извещения иностранного лица, участвующего в деле: 1) дипломатический; 2) с участием центральных органов; 3) прямой (обращение непосредственно в суды, компетентные разрешать экономические споры на территории запрашиваемых государств) [12].

Государства, подписавшие Киевское соглашение, участвуют в универсальных международных договорах, специально регулирующих порядок извещения иностранных лиц о судебном процессе. В частности, Республика Армения, Республика Беларусь, Кыргызская Республика, Российская Федерация, Республика Узбекистан, Украина являются участниками Конвенции по вопросам гражданского процесса (совершена 1 марта 1954 года в г. Гааге) [13]. Республика Армения, Республика Беларусь, Российская Федерация, Украина являются участниками Конвенции о вручении за границей судебных и внесудебных документов по гражданским или торговым делам (совершена 15 ноября 1965 года в г. Гааге) [14].

В соответствии со статьями 2 и 3 Гаагской конвенции 1965 года вручение судебных и внесудебных документов производится путем обращения органа или судебного должностного лица запрашивающего государства с 
запросом о вручении документов к центральному органу запрашиваемого государства, назначенного принимать такие запросы. Дальнейшее вручение судебных и внесудебных документов адресату в запрашиваемом государстве производится указанными центральным органом способами, установленными в статье 5 данной Конвенции.

Согласно статье 10 Гаагской конвенции 1965 года, если запрашиваемое государство не заявляет возражений, названная Конвенция не препятствует:

1) возможности непосредственно посылать по почте судебные документы лицам, находящимся за границей;

2) возможности судебных и иных должностных лиц или других компетентных лиц запрашивающего государства вручать судебные документы, прибегая непосредственно к услугам судебных и иных должностных лиц или других компетентных лиц запрашиваемого государства;

3) возможности любого лица, участвующего в судебном разбирательстве, вручать судебные документы, непосредственно прибегая к услугам судебных и иных должностных лиц или других компетентных лиц запрашиваемого государства.

Данная Конвенция упростила процедуру вручения судебных и внесудебных документов за границей, улучшив организацию судебной взаимопомощи. По своему характеру порядок, устанавливаемый Гаагской конвенцией 1965 года, относится ко второму способу извещения, т. е. с участием центрального органа, но в отличие от его классической формы он более доступен [15].

Оговорки относительно применения статьи 10 Гаагской конвенции 1965 года сделали Российская Федерация и Украина. Российская Федерация указала, что вручение документов способами, предусмотрен- ными в статье 10 Конвенции, в Российской Федерации не допускается.

В связи с формированием новой, эффективной модели судопроизводства хотелось бы обратить внимание на следующее. В соответствии с требованиями части 3 статьи 253 АПК Российской Федерации в случаях, если иностранные лица, участвующие в деле, находятся вне пределов Российской Федерации, такие лица извещаются о судебном разбирательстве путем направления поручения в учреждение юстиции или другой компетентный орган иностранного государства, и в этих случаях срок рассмотрения дела продлевается на срок, установленный договором о правовой помощи для направления соответствующих поручений, а при отсутствии в договоре этого срока или отсутствии указанного договора не более чем на шесть месяцев. Безусловно, в самой процессуальной норме заложено основание значительного увеличения сроков рассмотрения дел с участием иностранного элемента, в то время как Гаагская конвенция 1965 года предоставляет государству возможность использовать более доступный порядок извещения сторон спора, нацеленный на сокращение сроков рассмотрения дел.

В ситуации одновременного действия нескольких международных договоров «актуальным и требующим решения является вопрос о соотношении норм Киевского соглашения с нормами других специальных международных договоров, регламентирующих процедуру извещения о ведущихся в иностранных судах разбирательствах» [16].

Экономический Суд пришел к выводу о том, что при применении пункта г) статьи 9 Соглашения от 20 марта 1992 года и оценке надлежащего характера извещения о процессе стороны, против которой вынесено решение, суды государств - участников Соглашения должны решать вопрос о соотношении при- 
менимых в конкретном государстве норм международных договоров, национального законодательства, оценивать представленные сторонами доказательства извещения (неизвещения) в совокупности с точки зрения относимости, допустимости, достоверности и достаточности, имея при этом в виду необходимость обеспечения стороне, против которой вынесено решение иностранным судом, права на справедливое разбирательство и права на судебную защиту.

Следует отметить, что в соответствии с постановлением Пленума Высшего Арбитражного Суда Российской Федерации от 11 июня 1999 года № 8 «О действии международных договоров Российской Федерации применительно к вопросам арбитражного процесса» Суд, применяя правила, установленные нормами международных договоров, определяет действие этих правил во времени и пространстве в соответствии с разделом 2 части III Венской конвенции о праве международных договоров от 23 мая 1969 года. Суд учитывает, что двусторонний международный договор является специальным нормативным актом по отношению к многосторонним международным договорам регионального и всеобщего характера (пункт 3).

По мнению Н. Г. Беляевой, в силу разъяснений, содержащихся в постановлении Пленума Высшего Арбитражного Суда Российской Федерации от 11 июня 1999 года, и исходя из положений статьи 30 Венской конвенции о применении последовательно заключенных международных договоров, имеющих один предмет правового регулирования, Соглашение от 20 марта 1992 года имеет приоритет над Гаагской конвенцией 1965 года и Гаагской конвенцией 1954 года, а Гаагская конвенция 1965 года, в свою очередь, имеет приоритет над Гаагской конвенцией 1954 года. В отношении же применения норм двусторонних договоров о правовой помощи следует учитывать, по мнению данного автора, что согласно пункту 3 постановления нормы двустороннего международного договора имеют приоритет. Это также следует из пункта 2 информационного письма Высшего Арбитражного Суда Российской Федерации от 22 декабря 2005 года № 96 «Обзор практики рассмотрения арбитражными судами дел о признании и приведении в исполнение решений иностранных судов, об оспаривании решений третейских судов и о выдаче исполнительных листов на принудительное исполнение решений третейских судов», согласно которому, если участники международного многостороннего договора заключили также международный двусторонний договор о правовой помощи, то суд применяет первый договор только к тем отношениям, которые не урегулированы двусторонним договором [17].

При рассмотрении проблемы применения толкуемой нормы, кроме того, закономерно возникает вопрос о соотношении норм Минской конвенции и Киевского соглашения, т. к. оба международных договора регулируют вопросы признания и исполнения иностранных судебных решений на территории СНГ [18, с. 46].

Экономический Суд, исследуя соотношение применения названной нормы Соглашения от 20 марта 1992 года с аналогичными статьями Минской и Кишиневской конвенций, подтвердил сделанные ранее выводы о том, что «государствам - участникам Соглашения от 20 марта 1992 года при оказании взаимной правовой помощи, ... признании и приведении в исполнение иностранных решений по хозяйственным спорам надлежит руководствоваться Соглашением, исходя из того, что положения Минской и Кишиневской конвенций (статья 82 и пункт 3 статьи 118 соответственно) не за- 
трагивают прав и обязательств участников Соглашения от 20 марта 1992 года, а также в силу специального характера его норм» [19]. При этом учитывалось и Соглашение о порядке взаимного исполнения решений арбитражных, хозяйственных и экономических судов на территориях государств - участников Содружества от 6 марта 1998 года [20], заключенное в развитие Соглашения от 20 марта 1992 года. Согласно статье 3 «вступившее в законную силу решение компетентного суда одной Договаривающейся Стороны исполняется на территории другой Договаривающейся Стороны в бесспорном порядке». Однако Суд обратил внимание на указание части пятой статьи 9 названного договора о том, что в приведении в исполнение судебного решения взыскателю может быть отказано в случае несоблюдения положений статей 8 и 9 Соглашения от 20 марта 1992 года.

В работах российских ученых-юристов обращается внимание, что международными договорами о правовой помощи могут быть предусмотрены иные, нежели предусмотренные статьей 241 Арбитражного процессуального кодекса Российской Федерации, правила [21]. Так, для исполнения решений по хозяйственным спорам между Российской Федерацией и Республикой Беларусь Соглашением между Российской Федерацией и Республикой Беларусь о порядке взаимного исполнения судебных актов арбитражных судов Российской Федерации и хозяйственных судов Республики Беларусь от 17 января 2001 года предусмотрен национальный режим исполнения. Согласно статье 1 данного Соглашения судебные акты компетентных судов не нуждаются в специальной процедуре признания и исполняются в таком же порядке, что и судебные акты судов своего государства на основании ис- полнительных документов судов, принявших решение [22].

Следует отметить, что при этом также должны учитываться требования Соглашения от 20 марта 1992 года, на положениях которого основано Соглашение от 17 января 2001 года. Высшей судебной инстанцией Российской Федерации разъяснено, что «...согласно статьям 4 и 9 Соглашения от 20 марта 1992 года условиями взаимного исполнения судебных решений являются соблюдение права на защиту каждой из сторон в споре... Поэтому в случае возражений должника против исполнения судебного решения и представления им доказательств того, что при вынесении этого решения не были обеспечены надлежащее его извещение..., вопрос о правомерности исполнения оспариваемого решения по жалобе должника подлежит рассмотрению арбитражным судом в соответствии с положениями статьи 9 Соглашения от 20 марта 1992 года» [23].

Высший Арбитражный Суд Российской Федерации подтвердил, что, несмотря на то, что в Киевском соглашении порядок извещения сторон о процессе в суде иностранного государства не детализирован, арбитражные суды Российской Федерации исходят из того, что такое извещение осуществляется в рамках оказания международной правовой помощи посредством направления поручения о вручении судебных документов, которое запрашиваемое государство исполняет в соответствии со своим законодательством. Одновременно Высший Арбитражный Суд Российской Федерации сообщил, что при отсутствии в международном праве жестких норм о приоритете и соотношении международных договоров по аналогичному или схожему предмету арбитражные суды Российской Федерации в настоящее время при выборе способа извещения отдают предпочтение такому способу, который является более простым и эффектив- 
ным с точки зрения процедуры и позволяет достоверно убедиться в том, что извещение иностранного лица было осуществлено надлежащим образом, в срок, достаточный для обеспечения возможности участия в судебном разбирательстве либо представления письменного отзыва на исковое заявление. С этой точки зрения более простым и эффективным в аспекте сроков может оказаться извещение арбитражными судами Российской Федерации лиц, находящихся в Республике Беларусь, по почте, нежели чем с использованием процедуры, регламентированной Киевским соглашением [24].

Соотношение пункта г) статьи 9 Соглашения от 20 марта 1992 года и законодательства государств-участников о порядке извещения иностранных лиц о судебном процессе предопределяется тем, что в указанной норме он не конкретизирован.

Как указывается в юридической литератуpe, механизм судебного извещения включает несколько элементов, создающих в совокупности реальную возможность участников судебного процесса присутствовать в судебном заседании или при совершении судом отдельного процессуального действия:

- обязательность направления судом копий судебных актов, содержащих четкую информацию о времени и месте судебного заседания или совершения отдельного процессуального действия;

- порядок направления, обеспечивающий получение лицом, участвующим в деле, копии судебного акта;

- $\quad$ запрещение суду проводить заседание или совершать отдельное процессуальное действие при отсутствии доказательств извещения участников процесса о времени и месте судебного разбирательства;

- обязательность (безусловность) отмены судебного акта, принятого в отсутствие кого-либо из участвующих в деле лиц, не извещенных надлежащим образом о времени и месте судебного заседания [25]. Процессуальными кодексами ряда государств - участников Соглашения от 20 марта 1992 года прямо установлено, что иностранные лица извещаются о судебном процессе путем направления поручения в компетентные органы иностранного государства, т. е. в порядке взаимного оказания правовой помощи (часть третья статьи 241 Хозяйственного процессуального кодекса Республики Беларусь, часть 3 статьи 253 Арбитражного процессуального кодекса Российской Федерации, статья 232 Экономического процессуального кодекса Республики Таджикистан).

Другими государствами - участниками Соглашения порядок извещения иностранных юридических и физических лиц о судебном разбирательстве путем направления судебных поручений в процессуальном законодательстве отдельно не регламентирован. В частности, Гражданский процессуальный кодекс Республики Казахстан детально устанавливает общие правила направления и вручения судебных уведомлений, которые применимы, прежде всего, к юридическим и физическим лицам, находящимся или проживающим в данном государстве (статьи 129-135), и распространяет эти правила на иностранных юридических и физических лиц (статья 413). Такой же порядок предусмотрен в Гражданском процессуальном кодексе Республики Армения (статья 243), Гражданском процессуальном кодексе Кыргызской Республики (статья 392), Хозяйственном процессуальном кодексе Республики Узбекистан (статья 222).

Суд при вынесении консультативного заключения учитывал также разъяснения высших судебных инстанций и судебную практику государств - участников Соглашения от 20 марта 1992 года по вопросу о порядке 
извещения о судебном процессе иностранных юридических и физических лиц.

Суды Республики Казахстан, придерживаясь в основном порядка извещения путем судебных поручений, допускают иные способы уведомлений, например, путем почтовых отправлений (определения Апелляционной судебной коллегии по гражданским и административным делам Павлодарского областного суда от 10 января 2013 года и от 27 мая 2013 года, Специализированного межрайонного экономического суда г. Алматы от 9 августа 2013 года, Специализированного межрайонного экономического суда по Восточно-Казахстанской области от 14 мая 2013 года) [26].

В соответствии с пунктами 16-20 постановления Пленума Высшего Арбитражного Суда Российской Федерации от 11 июня 1999 года № 8 выполнение поручений о совершении отдельных процессуальных действий, включая вручение документов участнику арбитражного процесса, производится в порядке, предусмотренном международными договорами с участием Российской Федерации и национальным законодательством Российской Федерации.

Как отмечают российские правоведы, арбитражное процессуальное законодательство устанавливает так называемый национальный правовой режим для защиты интересов иностранных лиц, участвующих в арбитражном процессе. В соответствии с национальным правовым режимом иностранным гражданам, предприятиям, лицам без гражданства предоставляется такой же режим защиты, как физическим и юридическим лицам Российской Федерации, на них распространяются одинаковые процессуальные права. Однако национальный режим не исключает, a, наоборот, предполагает наличие особенностей в рассмотрении дел с участием иностранных субъектов, касающихся нескольких фундаментальных вопросов, в том числе порядок судебного извещения иностранных участников процесса, который зависит от того, какую конвенцию ратифицировало то или иное государство [27].

В анализируемом консультативном заключении Суд установил, что извещение стороны о процессе в государствах - участниках Соглашения допускается как в порядке направления судебных поручений об оказании международной правовой помощи, так и в ином предусмотренном национальным законодательством порядке. При исполнении поручения об оказании правовой помощи компетентные суды и иные органы, у которых испрашивается помощь, применяют законодательство своего государства, если иное не предусмотрено международными договорами. Такая практика национальных судов государств - участников Соглашения не противоречит положениям данного Соглашения, поскольку в нем отсутствует четкая детализация порядка извещения стороны о судебном процессе.

Однако отсутствие детализации порядка извещения стороны о судебном процессе вызывает затруднения в применении Соглашения.

Суды большинства государств исследуют по существу как доказательства надлежащего извещения о процессе стороны, против которой вынесено решение, представленные лицом, инициирующим судебное производство об исполнении решения иностранного суда (статья 8), так и доказательства отсутствия надлежащего извещения, представленные в рамках этого же производства стороной, против которой вынесено решение (пункт г) статьи 9). Наличие доказательств надлежащего извещения о процессе стороны, против которой вынесено решение, рассматривается судами государств - участников Соглашения 
в качестве условия вынесения судебного постановления о приведении его в исполнение. В связи с этим само по себе соблюдение судом, вынесшим решение, правил национального законодательства, регулирующих извещение о судебном процессе, не исключает возможности отказа судом государства, где испрашивается исполнение, в приведении решения в исполнение согласно пункту г) статьи 9 Соглашения от 20 марта 1992 года, если он на основании доводов и доказательств стороны, против которой вынесено решение, сочтет, что извещение не являлось надлежащим. В случае же извещения посредством судебного поручения появляются бесспорные доказательства и дополнительные гарантии исполнения судебного акта.

В результате Суд пришел к выводу о том, что для установления в рамках Содружества Независимых Государств единообразной практики извещения стороны о судебном процессе целесообразно выработать на многостороннем (двустороннем) уровне единый порядок извещения. Для целей применения пункта г) статьи 9 Соглашения о порядке разрешения споров, связанных с осуществлением хозяйственной деятельности, от 20 марта 1992 года извещение стороны о судебном процессе должно обеспечивать реальную возможность участвовать в судебном разбирательстве и защищать свои права. Порядок и сроки направления извещения должны быть такими, чтобы извещаемая сторона имела достаточно времени для подготовки к судебному разбирательству и для явки в суд.

Подобная детализация может проводиться с учетом международного опыта, в том числе положений Конвенции о вручении за границей судебных и внесудебных документов по гражданским или торговым делам (совершена 15 ноября 1965 года в г. Гааге), специально регулирующих порядок извещения иностран- ных лиц о судебном процессе, участниками которой являются некоторые государства участники Соглашения от 20 марта 1992 года.

Отдельно следует остановиться на проблеме исполнения в государствах - участниках СНГ актов иностранных судов о принятии обеспечительных мер.

Вопрос об обеспечительных мерах в международном гражданском процессе вызывает повышенный интерес в литературе [28] и судебной практике [29]. Целевое назначение этих мер, заключающееся в гарантировании возможности полного и своевременного исполнения судебного решения, обусловливает присутствие соответствующих норм в процессуальном законодательстве всех государств - участников Содружества. Однако в судопроизводстве с участием иностранных физических и юридических лиц может возникнуть необходимость применения обеспечительных мер на территории другого государства - участника Содружества, на которую юрисдикция суда, разрешающего спор, не распространяется.

Действующие в рамках Содружества международные договоры, составляющие на сегодняшний день правовую базу СНГ по вопросам взаимного оказания правовой помощи, - Киевское соглашение, Минская и Кишиневская конвенции - однозначных положений в отношении обеспечительных мер не содержат.

Минская и Кишиневская конвенции (статья 6), равно как и Киевское соглашение (статья 5), наряду с указанием на выполнение процессуальных действий в порядке взаимного оказания правовой помощи, устанавливают уточняющий перечень, в котором такого процессуального действия, как применение обеспечительных мер, не содержится. В Кишиневской конвенции применение обеспечительной меры в виде наложения 
ареста на имущество, включая денежные средства на банковских счетах, в целях обеспечения иска вынесено за рамки взаимного оказания правовой помощи и предусмотрено статьей 54 данной Конвенции, которая относится к процедуре признания и исполнения решений судов.

Заслуживает внимания в связи с этим рассмотрение Экономическим Судом 14 апреля 2014 года запроса Совета председателей высших арбитражных, хозяйственных, экономических и других судов, разрешающих дела по спорам в сфере экономики, о толковании части второй статьи 5 Соглашения от 20 марта 1992 года и разъяснении, включает ли взаимное оказание правовой помощи выполнение такого процессуального действия, как принятие обеспечительных мер по поручению иностранного суда [30].

По мнению Экономического Суда, конструкция толкуемой нормы указывает на открытый, не исчерпывающий характер перечня процессуальных действий, которые могут быть совершены в порядке оказания правовой помощи, что может предполагать выполнение наряду с перечисленными и иных процессуальных действий. Принимая во внимание, что при исполнении поручений об оказании правовой помощи компетентные суды и иные органы, у которых испрашивается помощь, применяют законодательство своего государства (часть четвертая статьи 5 Соглашения), Суд проанализировал соответствующие нормативные правовые акты государств - участников Соглашения.

В отличие от неоднозначного регулирования порядка извещения иностранных лиц, установленного по предыдущему делу, нормы процессуальных кодексов государств - участников Киевского соглашения содержат схожие положения, устанавливающие открытый перечень отдельных процессуальных действий, которые может осуществить компетентный суд по поручению иностранного суда; в этот перечень не включено такое процессуальное действие, как принятие обеспечительных мер, также как оно не включено в перечень процессуальных действий, перечисленных в части второй статьи 5 Киевского соглашения (статья 244 Хозяйственного процессуального кодекса Республики Беларусь, пункт 1 статьи 423 Гражданского процессуального кодекса Республики Казахстан, статья 256 Арбитражного процессуального кодекса Российской Федерации, статья 456.1 Гражданского процессуального кодекса Азербайджанской Республики, статья 247 Гражданского процессуального кодекса Республики Армения, статья 378 Гражданского процессуального кодекса Кыргызской Республики, статья 235 Экономического процессуального кодекса Республики Таджикистан, статья 127 Хозяйственного процессуального кодекса Украины).

По информации, поступившей в Экономический Суд из верховных, высших хозяйственных, экономических судов, принятие обеспечительных мер по поручению иностранного суда не входит в объем правовой помощи (Высший Арбитражный Суд Российской Федерации, Верховный суд Туркменистана, Высший экономический суд Республики Таджикистан, Высший хозяйственный суд Украины) либо судебная практика по данному вопросу отсутствует (Верховный Суд Республики Беларусь, Верховный Суд Республики Казахстан, Верховный суд Кыргызской Республики).

Судебные акты иностранных судов о применении обеспечительных мер, отмечает И. В. Решетникова, не подлежат признанию и принудительному исполнению на территории Российской Федерации, поскольку не яв- 
ляются окончательными судебными актами по существу спора, вынесенными в состязательном процессе. Кроме того, из буквального содержания статьи 241 Арбитражного процессуального кодекса Российской Федерации следует, что признанию и приведению в исполнение подлежат решения судов иностранных государств, принятые ими по существу спора. Положения Арбитражного процессуального кодекса Российской Федерации не предусматривают возможности приведения в исполнение иных, помимо решений, актов судов иностранных государств, принятых ими до или после рассмотрения спора по существу. Положения Соглашения о порядке разрешения споров, связанных с осуществлением хозяйственной деятельности, и Конвенции о правовой помощи и правовых отношениях по гражданским, семейным и уголовным делам, касающиеся вопросов приведения в исполнение решений государственных судов, также не содержат указания на возможность приведения в исполнение иных, помимо решений, судебных актов судов договаривающихся государств (пункт 26 информационного письма Президиума Высшего Арбитражного Суда Российской Федерации от 7 июля 2004 года № 78, определение Высшего Арбитражного Суда Российской Федерации от 23 июня 2008 года № 11934/04 по делу № А56-7455/2000) [30]. Аналогичный подход закреплен в пункте 33 постановления Пленума Высшего Арбитражного Суда Российской Федерации от 12 октября 2006 года № 55 «О применении арбитражными судами обеспечительных мер» [31].

Тем не менее Высший Арбитражный Суд Российской Федерации отметил, что в практике арбитражных судов Российской Федерации встречаются случаи обращения компетентных судов государств - участников
Киевского соглашения в компетентные суды Российской Федерации по вопросу принятия обеспечительных мер в рамках оказания правовой помощи, которые ими отклоняются [32].

Один из примеров приводится также в информационном письме Президиума Высшего Арбитражного Суда Российской Федерации от 9 июля 2013 года № 158 «Обзор практики по некоторым вопросам, связанным с рассмотрением арбитражными судами дел с участием иностранных лиц» [33] и касается обращения хозяйственного суда г. Киева в арбитражный суд в Российской Федерации с судебным поручением об оказании правовой помощи в виде наложения ареста на имущество российской компании, являющейся ответчиком по делу в украинском суде, со ссылкой на Киевское соглашение. Определением суда Российской Федерации в исполнении судебного поручения отказано на том основании, что «применение обеспечительных мер ...не входит в объем взаимной правовой помощи и не может быть осуществлено в порядке ее оказания судом одного государства на основании поручения суда другого государства, ...удовлетворение заявления о принятии обеспечительных мер по ходатайству иностранного суда ни положениями применимых международных договоров Российской Федерации, ни положениями АПК РФ не предусмотрено» (пункт 31).

Указанные обращения свидетельствуют о том, что, несмотря на схожие нормы процессуальных кодексов стран - участниц Киевского соглашения и сходную судебную практику, тем не менее такие обращения имеют место, соответственно, некоторые суды по-иному толкуют как нормы процессуальных кодексов, так и положения части второй статьи 5 Киевского соглашения.

Следовательно, открытый характер перечня процессуальных действий, оказываемых в порядке правовой помощи, на практике по- 
рождает неопределенность при применении части второй статьи 5 Киевского соглашения. В связи с этим Экономический Суд принял консультативное заключение о том, что в целях установления единообразной практики в вопросах применения обеспечительных мер в рамках взаимного оказания правовой помощи на пространстве Содружества Независимых Государств представляется целесообразной выработка на многостороннем или двустороннем уровне единого механизма в вопросах принятия к исполнению либо отказа в принятии к исполнению поручений, касающихся обеспечительных мер.

Суд исходил при этом из особенностей обеспечительных мер как средства защиты, применяемого в ускоренной судебной процедуре при оценке ограниченного круга доказательств и без вызова противной стороны, не всегда основанного на сбалансированной оценке интересов всех сторон процесса [34].

Представляет интерес и несколько иной аспект проблематики исполнения иностранных судебных актов в государствах - участниках СНГ, исследовавшийся Экономическим Судом.

Правительство Кыргызской Республики обратилось в Суд с запросом о толковании статьи 11 Конвенции о защите прав инвестора, заключенной 28 марта 1997 года в г. Москве (далее - Московская конвенция) [35]. Поводом для запроса послужило то обстоятельство, что третейским арбитражем Российской Федерации рассмотрены иски ряда инвесторов к Кыргызской Республике о возмещении ущерба на значительные суммы. В качестве основания для обращения истцов в данный третейский арбитраж названы нормы статьи 11 Московской конвенции, согласно которой споры по осуществлению инвестиций в рамках настоящей Конвенции рассматриваются судами или арбитражными судами стран
- участников споров, Экономическим Судом Содружества Независимых Государств и/или иными международными судами или международными арбитражными судами. При этом данный третейский арбитраж не был обозначен в качестве органа по рассмотрению споров по осуществлению инвестиций в рамках Московской конвенции ни в национальном законодательстве государства - участника спора, ни в международном договоре, стороной которого является государство - участник спора, ни в отдельном соглашении между инвестором и государством - участником спора.

Согласно пункту 3 части 2 статьи 239 АПК Российской Федерации государственный суд может отказать в выдаче исполнительного листа на принудительное исполнение решения третейского суда, принятого по спору, не предусмотренному третейским соглашением.

Надо отметить, что по сравнению с ранее рассмотренными в данной статье делами позиции высших и верховных судов государств - участников Московской конвенции, министерств иностранных дел, нормы процессуальных кодексов государств по спорному вопросу в рамках данного дела аналогичны, что значительно облегчило принятие Экономическим Судом 23 сентября 2014 года решения по результатам судебного исследования [36]. Принципиальный вывод Экономического Суда состоял в том, что положения статьи 11 Конвенции о защите прав инвестора от 28 марта 1997 года не могут рассматриваться в качестве арбитражного соглашения о рассмотрении спора по осуществлению инвестиций [37].

Приведенные судебные акты Экономического Суда, как можно заметить, выявляют проблемные аспекты соотношения международных договоров государств - участников СНГ и норм национального законодательства при исполнении иностранных судебных актов 
и устанавливают, каким образом эти проблемы могут быть решены, способствуя тем самым эффективному трансграничному исполнению судебных и арбитражных решений.

Г. Г. Шинкарецкая, говоря о пользе международных судов и арбитражей, разрешающих споры и разъясняющих право, подчеркивает, что истинная роль международных судебных процедур состоит в обеспечении господства права. Примат права в международных отношениях означает установление такого единого правопорядка во всем мире, который бы предоставлял каждому суверенному государству свободу действий в рамках общепризнанных юридических принципов и норм [38, с. 455]. С этим согласуется, на наш взгляд, утверждение о том, что принципиальная роль Суда Содружества Независимых Государств не ограничивается применением и толкованием международных договоров, связывающих государства Содружества, как это вытекает из формально закрепленных положений учредительных документов, поскольку, работая в этом направлении, Суд объективно способствует на основе достигнутого правового единообразия более тесному и свободному, по крайней мере, от юридических препятствий сотрудничеству стран СНГ [39].

\section{Библиография:}

1. Решетникова И. В. Судопроизводство в судах первой инстанции: сравнительно-правовой анализ через призму предстоящей унификации гражданского и арбитражного процессуального права. // Арбитражный и гражданский процесс. - 2015 - № 2. - С. 48-53.

2. [Электронный ресурс] // Единый реестр правовых актов и других документов Содружества Независимых Государств. URL: http://www.cis.minsk.by/reestr/ru/index.html\#reestr/view/text?doc=57 (дата обращения: 23.04.2015).

3. [Электронный ресурс] // Единый реестр правовых актов и других документов Содружества Независимых Государств. URL: http://www.cis.minsk.by/reestr/ru/index.html\#reestr/view/text?doc=192 (дата обращения: 23.04.2015).

4. [Электронный ресурс] // Единый реестр правовых актов и других документов Содружества Независимых Государств. URL: http://cis.minsk.by/reestr/ru/index.html\#reestr/view/text?doc=690 (дата обращения: 23.04.2015).

5. [Электронный ресурс] // Единый реестр правовых актов и других документов Содружества Независимых Государств. URL: http://www.cis.minsk.by/reestr/ru/index.html\#reestr/view/text?doc=1313 (дата обращения: 23.04.2015).

6. Бородаев В. Е., Жумабаева М. Е. О признании и исполнении решений иностранных судов в рамках Евразийского экономического сообщества. // Вестник Института законодательства и правовых исследований Республики Казахстан. - 2014. - № 3. - С. 137-143.

7. Симонова Н. С. Влияние консультативной юрисдикции международных региональных судебных органов на обеспечение выполнения обязательств по международным договорам. //Международное публичное и частное право. - 2015. - № 2. - С. 9-12.

8. Крохалев С. В. Категория публичного порядка в международном гражданском процессе. - С. - П.: Изд. дом Санкт-Петербургского университета, 2006. // КонсультантПлюс: Россия. Технология Проф. [Электронный ресурс] / ООО «ЮрСпектр».

9. Подробнее см. Афанасьев С. Ф. К проблеме реализации права быть выслушанным в суде при рассмотрении гражданских дел. - Вестник гражданского процесса. - 2012. - № 4. [Электронный ресурс] // КонсультантПлюс: Россия. Технология Проф. / ООО «ЮрСпектр».

10. Ерпылева Н. Ю. Понятие, источники и принципы международного гражданско-процессуального права // Законодательство и экономика. - 2012. - № 3. - С. 59-69. 
11. О толковании пункта г) статьи 9 Соглашения о порядке разрешения споров, связанных с осуществлением хозяйственной деятельности, от 20 марта 1992 года: консультативное заключение Экономического Суда СНГ, 26 апреля 2014 года № 01-1/4-13 [Электронный ресурс] // Экономический Суд Содружества Независимых Государств. URL: http://sudsng.org/download_files/rh/2014/zk_01-1_4-13_20140426.pdf (дата обращения: 20.04.2015).

12. Беляева Н. Г. Особенности рассмотрения дел с участием иностранных лиц в арбитражном суде: практическое пособие. - М.: Норма, 2012 .// КонсультантПлюс: Россия. Технология Проф. [Электронный ресурс] / ООО «ЮрСпектр».

13. [Электронный ресурс] // Гаагская конференция по международному частному праву. - URL: http://www. hcch.net/index en.php?act=conventions.status\&cid=33 (дата обращения: 23.04.2015).

14. [Электронный ресурс] //Гаагская конференция по международному частному праву. - URL: http://www. hcch.net/index_en.php?act=conventions.status\&cid=17 (дата обращения: 28.03.2015).

15. Беляева Н. Г. Особенности рассмотрения дел с участием иностранных лиц в арбитражном суде: практическое пособие. - М.: Норма,. 2012. [Электронный ресурс] // КонсультантПлюс: Россия. Технология Проф. / ООО «ЮрСпектр».

16. Письмо Высшего Арбитражного Суда Российской Федерации от 11 февраля 2014 года № ВАС-C01/ УМПС-202. // Архив Экономического Суда СНГ. - Дело № 01-1/4-13. - Т. 1. - С. 25-36.

17. Беляева Н. Г. Особенности рассмотрения дел с участием иностранных лиц в арбитражном суде: практическое пособие. - М.: Норма, 2012 . [Электронный ресурс] // КонсультантПлюс: Россия. Технология Проф. / ООО «ЮрСпектр».

18. Ерпылева Н. Ю., Батлер У. Э. Производство по делам с участием иностранных лиц в международном процессуальном праве России и Украины: современное правовое регулирование. // Международное право и международные организации. - 2013. - № 1(13). - С. 29-47.

19. Решение Экономического Суда СНГ, 21 февраля 2007 года № 01-1/2-06 [Электронный ресурс] // Экономический Суд Содружества Независимых Государств. URL: http://sudsng.org/download_files/rh/2007/ Rh_01-1_2-06_21022007.pdf (дата обращения: 20.04.2015).

20. [Электронный ресурс] // Единый реестр правовых актов и других документов Содружества Независимых Государств. URL: http://www.cis.minsk.by/reestr/ru/index.html\#reestr/view/text?doc=779 (дата обращения: 23.04.2015).

21. Практика применения Арбитражного процессуального кодекса Российской Федерации / О. В. Абознова, Н. Г. Беляева, М. А. Куликова и др.; отв. ред. И. В. Решетникова. 2-е изд., перераб. и доп. - М.: Юрайт. 2012. [Электронный ресурс] // КонсультантПлюс: Россия. Технология Проф. / ООО «ЮрСпектр».

22. [Электронный ресурс] URL: http://docs.cntd.ru/document/901838376 (дата обращения: 23.04.2015).

23. Информационное письмо Высшего Арбитражного Суда Российской Федерации (1 июня 2004 г. № C1-7/MO-627), Министерства юстиции Российской Федерации (28 января 2004 г.№ 06/899ЮЧ) и Центрального банка Российской Федерации (4 июня 2004 г. № 01-31/2020) по вопросам применения Соглашения между Российской Федерацией и Республикой Беларусь о порядке взаимного исполнения судебных актов арбитражных судов Российской федерации и хозяйственных судов Республики Беларусь [Электронный ресурc] URL: http://www.alppp.ru/law/pravosudie/3/ informacionnoe-pismo-vas-rf-ot-01-06-2004--s1-7mo-627-minyusta-rf-ot-28-01-2004--06899-y.pdf (дата обращения: 25.04.2015).

24. Письмо Высшего Арбитражного Суда Российской Федерации от 11 февраля 2014 года № ВАС-С01/ УМПС-202. // Архив Экономического Суда СНГ. - Дело № 01-1/4-13. - Т. 1. - С. 25-36.

25. Арбитражный процесс: учебник / А. В. Абсалямов, И. Г. Арсенов, Е. А. Виноградова и др.; отв. ред. В. В. Ярков. 4-е изд., перераб. и доп. - М.: Инфотропик-Медиа, 2010. [Электронный ресурс] // КонсультантПлюс: Россия. Технология Проф/ ООО «ЮрСпектр».

26. Письмо Верховного Суда Республики Казахстан от 20 февраля 2014 года № 9-2-5/1460. // Архив Экономического Суда СНГ. - Дело № 01-1/4-13. - Т. 1. - С. 41-60. 
27. Беляева Н. Г. Особенности рассмотрения дел с участием иностранных лиц в арбитражном суде: практическое пособие. - М.: Норма, 2012. [Электронный ресурс] // КонсультантПлюс: Технология Проф. / М., ООО «ЮрСпектр».

28. Подробнее см. Ерпылева Н. Ю., Клевченкова М. Н. Обеспечительные меры в международном гражданском процессе. - М., Юридическая электронная библиотека «ЮРИСТЛИБ» 2009. [Электронный ресурс] URL: http://www.juristlib.ru/book_6237.html (дата обращения: 26.03.2015); Котлярова В. В. Об основаниях и условиях применения обеспечительных мер: правовое регулирование и судебная практика. // Арбитражный и гражданский процесс. - 2014. - № 5. - С. 38-43.

29. 29. См., например, Обзор практики по некоторым вопросам, связанным с рассмотрением арбитражными судами дел с участием иностранных лиц: информационное письмо Президиума Высшего Арбитражного Суда Российской Федерации, 9 июля 2013 года № 158 [Электронный ресурc] URL: http://www.arbitr.ru/ as/pract/vas_info_letter/89295.html (дата обращения: 06.05.2015).

30. О толковании части второй статьи 5 Соглашения о порядке разрешения споров, связанных с осуществлением хозяйственной деятельности, от 20 марта 1992 года: консультативное заключение Экономического Суда СНГ от 14 апреля 2014 года № 01-1/3-13 [Электронный ресурс] // Экономический Суд Содружества Независимых Государств. URL: http://sudsng.org/download_files/rh/2014/zk_01-1_3-13_14042014.pdf (дата обращения 06.05.2015).

31. Практика применения Арбитражного процессуального кодекса Российской Федерации / О. В. Абознова, Н. Г. Беляева, М. А. Куликова и др.; отв. ред. И. В. Решетникова. 2-е изд., перераб. и доп. - М.: Юрайт. 2012. [Электронный ресурс] // КонсультантПлюс: Россия. Технология Проф. / ООО «ЮрСпектр»; Ерпылева Н. Ю., Клевченкова М. Н. Обеспечительные меры в международном гражданском процессе. - М., Юридическая электронная библиотека «ЮРИСТЛИБ», 2009. [Электронный ресурc] URL: http:// www.juristlib.ru/book_6237.html (дата обращения: 26.03.2015).

32. Письмо Высшего Арбитражного Суда Российской Федерации от 25 декабря 2013 года № ВАС-CO1/ УМПС-2512. // Архив Экономического Суда СНГ. - Дело № 01-1/3-13. - С. 105-108.

33. Обзор практики по некоторым вопросам, связанным с рассмотрением арбитражными судами дел с участием иностранных лиц: информационное письмо Президиума Высшего Арбитражного Суда Российской Федерации, 9 июля 2013 года № 158 [Электронный ресурc] URL: http://www.arbitr.ru/as/pract/ vas_info_letter/89295.html (дата обращения: 06.05.2015).

34. Ерпылева Н. Ю., Клевченкова М. Н. Обеспечительные меры в международном гражданском процессе M., Юридическая электронная библиотека «ЮРИСТЛИБ»2009. [Электронный ресуpc] URL: http://www. juristlib.ru/book_6237.html (дата обращения: 26.03.2015); Практика применения Арбитражного процессуального кодекса Российской Федерации / О. В. Абознова, Н. Г. Беляева, М. А. Куликова и др.; отв. ред. И. В. Решетникова. 2-е изд., перераб. и доп. - М.: Юрайт. 2012. [Электронный ресурс] // КонсультантПлюс: Россия. Технология Проф. / ООО «ЮрСпектр».

35. [Электронный ресурс] // Единый реестр правовых актов и других документов Содружества Независимых Государств. URL: http://www.cis.minsk.by/reestr/ru/index.html\#reestr/view/text?doc=693 (дата обращения: 11.05.2015).

36. О толковании статьи 11 Конвенции о защите прав инвестора от 28 марта 1997 года: решение Экономического Суда СНГ от 23 сентября 2014 года № 01-1/1-14 [Электронный ресурс] // Экономический Суд Содружества Независимых Государств. URL: http://sudsng.org/download_files/rh/2014/rh-01-1_14_23092014.pdf (дата обращения: 11.05.2015).

37. Подробнее о выводах Экономического Суда см. Э. Н. Нагорная, Д. Н. Северин. Компетенция международных арбитражных судов по рассмотрению инвестиционных споров на основании статьи 11 Конвенции о защите прав инвестора от 28.03.1997 [Электронный ресурс] // КонсультантПлюс: Беларусь. Технология 3000. - Минск, 2015.

38. Шинкарецкая Г. Г. «Классические» международные суды: роль в поддержании правопорядка. // Международное право и международные организации. - 2014. - № 3. - С. 452-457. 
39. Блажеев В.В.Поздравление Московской государственной юридической академии имени О. Е. Кутафина.// Материалы Международной научно-практической конференции, посвященной 20-летию Экономического Суда Содружества Независимых Государств (6 июля 2012 г.). - Минск: Арго-Графикс, 2012. - С. 59-60.

\section{References (transliterated):}

1. Reshetnikova I. V. Sudoproizvodstvo v sudakh pervoi instantsii: sravnitel'no-pravovoi analiz cherez prizmu predstoyashchei unifikatsii grazhdanskogo i arbitrazhnogo protsessual'nogo prava. // Arbitrazhnyi i grazhdanskii protsess. - 2015 - № 2. - S. 48-53.

2. Borodaev V. E., Zhumabaeva M. E. O priznanii i ispolnenii reshenii inostrannykh sudov v ramkakh Evraziiskogo ekonomicheskogo soobshchestva. // Vestnik Instituta zakonodatel'stva i pravovykh issledovanii Respubliki Kazakhstan. - 2014. - № 3. - S. 137-143.

3. Simonova N. S. Vliyanie konsul'tativnoi yurisdiktsii mezhdunarodnykh regional'nykh sudebnykh organov na obespechenie vypolneniya obyazatel'stv po mezhdunarodnym dogovoram. //Mezhdunarodnoe publichnoe i chastnoe pravo. - 2015. - № 2. - S. 9-12.

4. Krokhalev S. V. Kategoriya publichnogo poryadka v mezhdunarodnom grazhdanskom protsesse. - S. - P.: Izd. dom Sankt-Peterburgskogo universiteta, 2006. // Konsul'tantPlyus: Rossiya. Tekhnologiya Prof. [Elektronnyi resurs] / OOO «YurSpektr».

5. Afanas'ev S. F. K probleme realizatsii prava byt' vyslushannym v sude pri rassmotrenii grazhdanskikh del. Vestnik grazhdanskogo protsessa. - 2012. - № 4. [Elektronnyi resurs] // Konsul’tantPlyus: Rossiya. Tekhnologiya Prof. / OOO «YurSpektr».

6. Erpyleva N. Yu. Ponyatie, istochniki i printsipy mezhdunarodnogo grazhdansko-protsessual'nogo prava // Zakonodatel'stvo i ekonomika. - 2012. - № 3. - S. 59-69.

7. Belyaeva N. G. Osobennosti rassmotreniya del s uchastiem inostrannykh lits v arbitrazhnom sude: prakticheskoe posobie. - M.: Norma, 2012 .// Konsul'tantPlyus: Rossiya. Tekhnologiya Prof. [Elektronnyi resurs] / OOO «YurSpektr».

8. Belyaeva N. G. Osobennosti rassmotreniya del s uchastiem inostrannykh lits v arbitrazhnom sude: prakticheskoe posobie. - M.: Norma,. 2012. [Elektronnyi resurs] // Konsul'tantPlyus: Rossiya. Tekhnologiya Prof. / OOO «YurSpektr».

9. Belyaeva N. G. Osobennosti rassmotreniya del s uchastiem inostrannykh lits v arbitrazhnom sude: prakticheskoe posobie. - M.: Norma, 2012 . [Elektronnyi resurs] // Konsul'tantPlyus: Rossiya. Tekhnologiya Prof. / OOO «YurSpektr».

10. Erpyleva N. Yu., Batler U. E. Proizvodstvo po delam s uchastiem inostrannykh lits v mezhdunarodnom protsessual'nom prave Rossii i Ukrainy: sovremennoe pravovoe regulirovanie. // Mezhdunarodnoe pravo i mezhdunarodnye organizatsii. - 2013. - № 1(13). - S. 29-47.

11. Belyaeva N. G. Osobennosti rassmotreniya del s uchastiem inostrannykh lits v arbitrazhnom sude: prakticheskoe posobie. - M.: Norma, 2012. [Elektronnyi resurs] // Konsul'tantPlyus: Tekhnologiya Prof. / M., OOO «YurSpektr».

12. Erpyleva N. Yu., Klevchenkova M. N. Obespechitel'nye mery v mezhdunarodnom grazhdanskom protsesse. - M., Yuridicheskaya elektronnaya biblioteka «YuRISTLIB» 2009. [Elektronnyi resurs] URL: http://www.juristlib.ru/ book_6237.html (data obrashcheniya: 26.03.2015); Kotlyarova V. V. Ob osnovaniyakh i usloviyakh primeneniya obespechitel'nykh mer: pravovoe regulirovanie i sudebnaya praktika. // Arbitrazhnyi i grazhdanskii protsess. 2014. - № 5. - S. 38-43.

13. Erpyleva N. Yu., Klevchenkova M. N. Obespechitel'nye mery v mezhdunarodnom grazhdanskom protsesse - M., Yuridicheskaya elektronnaya biblioteka «YuRISTLIB»2009. [Elektronnyi resurs] URL: http://www. juristlib.ru/book_6237.html (data obrashcheniya: 26.03.2015); Praktika primeneniya Arbitrazhnogo protsessual'nogo kodeksa Rossiiskoi Federatsii / O. V. Aboznova, N. G. Belyaeva, M. A. Kulikova i dr.; otv. red. I. V. Reshetnikova. 2-e izd., pererab. i dop. - M.: Yurait. 2012. [Elektronnyi resurs] // Konsul'tantPlyus: Rossiya. Tekhnologiya Prof. / OOO «YurSpektr». 
DOI: $10.7256 / 2226-6305.2015 .3 .15391$

При цитировании этой статьи сноска на доі обязательна

Международное право и международные организации•3•2015

International Law and International Organizations

14. E. N. Nagornaya, D. N. Severin. Kompetentsiya mezhdunarodnykh arbitrazhnykh sudov po rassmotreniyu investitsionnykh sporov na osnovanii stat'i 11 Konventsii o zashchite prav investora ot 28.03.1997 [Elektronnyi resurs] // Konsul'tantPlyus: Belarus'. Tekhnologiya 3000. - Minsk, 2015.

15. Shinkaretskaya G. G. «Klassicheskie» mezhdunarodnye sudy: rol' v podderzhanii pravoporyadka. // Mezhdunarodnoe pravo i mezhdunarodnye organizatsii. - 2014. - № 3. - S. 452-457.

16. Blazheev V. V. Pozdravlenie Moskovskoi gosudarstvennoi yuridicheskoi akademii imeni O. E. Kutafina. // Materialy Mezhdunarodnoi nauchno-prakticheskoi konferentsii, posvyashchennoi 20-letiyu Ekonomicheskogo Suda Sodruzhestva Nezavisimykh Gosudarstv (6 iyulya 2012 g.). - Minsk: Argo-Grafiks, 2012. - S. 59-60. 